DOI: https://doi.org/10.18524/2519-2523.2018.13.149392

УДК 94(477)

\title{
"ON PROTECTION OF REVOLUTION" - COMPETITION OF CREATIVE WORKS OF MASTERS: IDEAS, CONDUCTING METHODS, AWARDS
}

\author{
Olena Bondoverer \\ Methodist of the department of MAN \\ Odessa Regional Humanitarian Center \\ out-of-school education and upbringing \\ 4, Tennista Str., Odessa, 6500, Ukraine \\ man.odessa22@gmail.com
}

In March 2018, a regional competition for research works "On the Defense of the Revolution" devoted to the 100th anniversary of the Ukrainian Army and the Ukrainian Revolution was held for high school students and schools in Odesa. The Odessa Regional Humanitarian Center for Out-of-school Education and Higher Education together with the Faculty of History and Philosophy of Odessa National University I. I. Mechnikov. The main goal of the event was to popularize the history of Ukrainian state creation, the discovery and development of creatively gifted student youth, the implementation of national patriotic education of citizens and the formation of national identity. The competition was held with the assistance of senior officers and Cossacks of the Black Sea Haydamaky Union of the Ukrainian Cossacks.

Key words: competition, 100th anniversary of the Ukrainian Army, 10th anniversary of the Ukrainian Revolution, the Black Sea Haydamaky Union of the Uranian Cossacks, Moscow State Medical University, Odesa Regional Humanitarian Center for Out-of-school Education and Upbringing, Faculty of History and Philosophy, I. I. Mechnikov Odessa National University, Department of History of Ukraine.

Олена Бондаровер

Методист вищій категорії МАН Одеським обласним гуманітарним центром позашкільної освіти та виховання Вум. Теніста,4, Одеса, 6500, Україна man.odessa22@gmail.com

\section{"НА ЗАХИСТІ РЕВОАЮЦІї" - КОНКУРС ТВОРЧИХ РОБІТ УЧНІВ: ІДЕÏ, МЕТОДИКА ПРОВЕДЕННЯ, НАГОРОДИ}

У березня 2018 р. для учнів старших класів гімназій та шкіл м. Одеси був проведений обласний конкурс досліднииъких робіт "На захисті революиї̈,, присвячений 100-річчю Українсъкого війсъка та Українсъкої Революиії. Організаторами стали Одеський обласний гуманітарний иентр позашкільної освіти та виховання спільно з факультетом історії та фрілософії Одеського наиіонального університету ім. I. I. Мечникова. Основною метою проведення заходу було популяризаиія історії українського державотворення, виявлення та розвиток творчо обдарованої учнівської молоді, реалізаиї національнопатріотичного виховання громадян та формуванню національної ідентичності. Конкурс проходив за сприянням у старшин та козаків Чорноморського Гайамаџъкого з'єднання Українського козаитва. 
Ключові слова: конкурс, 100-річчя Украӥнсъкої війсъка, 100-річчя Українсъкої революиї, Чорноморсъке Гайдамаиъке з'эднання Ураїнсъкого козаитва, МАН, Одесъкий обласний гуманітарний иентр позашкільної освіти та виховання, фракультет історії та фрілософрії Одеського національного університету іл. I. I. Мечникова, кафедра історії України.

Протягом гуманітарним центром позашкільної освіти та виховання спільно 3 факультетом історії та філософії Одеського національного університету iм. I. I. Мечникова був проведений обласний конкурс дослідницьких робіт "На захисті Революиї̈, присвячений 100-річчю Українського війська. У конкурсі розглядались роботи учнів старших класів за трьома номінаціями: "Українське військо (1917-1921 рр.)"; "Українське козацтво, як прообраз української армії; Українська армія сьогодні».

Основною метою проведення заходу було популяризація історії українського державотворення, виявлення та розвиток творчо обдарованої учнівської молоді, реалізації національно-патріотичного виховання громадян та формуванню національної ідентичності.

У конкурсі взяли участь учні з таких районів: Болградський, Захарівський, Іванівський, Кілійський, Кодимський, Аиманський, Подільський, Овідіопольський, Татарбунарський, Роздільнянський та Малиновського, Приморського, Київського Суворовського районів м. Одеса; Красносіцьська ОТГ та організатори.

Конкурс відбувся у два тури. I тур - відбірковий (заочний) проходив у Аютому - березні 2018 року. Членами журі було розглянуто 52 конкурсні роботи по основним тематичним напрямам:

- Українське військо (1917-1921 рр.) - 21 робота;

- Українське козацтво, як прообраз української армії - 21 робота;

- Українська армія сьогодні - 10 робіт.

Переможці були запрошені до фінального туру для доповіді по секціям на Всеукраїнські науковій конференції 3 історії України студентів та аспірантів "Хаджибеївські читання", який проходив 23 березня 2018 р. на факультеті історії та філософії Одеського національного університету ім. I. І. Мечникова. Тези учнів-переможців увійшли до збірки матеріалів цієї наукової конференції - що $є$ першим досвідом надрукованих наукових видань (Див: Матеріали Всеукраїнської наукової конференції з історії України студентів та аспірантів "Хаджибеївські читання" / колектив авторів. - Одеса, 2018).

Висловлюемо ширу подяку за сприяння у організаиї та проведенні Конкурсу старшинам та козакам Чорноморського Гайдамаиького з'єднання Українського козачтва, зокрема отаману полковнику Гуиалюку Сергію.

Значну підтримку у організаиї виступів учнів-переможиів та публікаиї іхніх тез-доповідей надали студенти та магістри кафедри історії України фракультету історії та фрілософії - Уляна Громович, Ксенія Сорокіна, Вікторія Нікічук та вікторія Герасименко. 


\section{Елена Бондаровер \\ "Ha заците Революиии" - конкурс творческих работ учацихся: идеи, методика проведения, награды}

В марте 2018 г. для учашихся старших классов гимназий и школ г. Одессы был проведен областной конкурс исследовательских работ "На зашите Революиии", посвяченный 100-летию Украинского войска и Украинской революиии. Организаторами стали Одесский областной гуманитарный иентр внешкольного образования и воспитания совместно с факультетом истории и философии Одесского наиионального университета им. И. И. Мечникова. Основной иелью проведения мероприятия была популяризаиия истории украинского государства, выявление и развитие творчески одаренной учашейся молодежи, реализаиии наииональнопатриотического воспитания граждан и формированию наииональной идентичности. Конкурс проходил при содействии старшин и казаков Черноморского Гайдамаикого соединения Украинского казачества.

ключевые слова: конкурс, 100-летие Украинской армии, 100-летие Украинской революиии, Черноморское Гайдамаикое соединение Украинского казачества, МАН, Одесский областной гуманитарный иентр внешкольного образования и воспитания, фракультет истории и философии Одесского национального университета им. И. И. Мечникова, кафедра истории Украины.

Отримано 21.11.2018 p. 